\title{
Sosialisasi Energi Baru Terbarukan dan Lingkungan Hidup Untuk Masyarakat Desa Sukawali KAB. Tangerang, Banten
}

\author{
Tasdik Darmana ${ }^{1}$; Retno Aita Diantari ${ }^{2}$; Zaenal $^{3}$; Syarif Hidayat ${ }^{4}$; Jumiati \\ Soetjipto Soewono $^{6}$; I Made Indradjaja ${ }^{7}$ \\ 1, 2, 3, 4, 5, 6, 7 Program Studi Teknik Elektro, Fakultas Teknik, Sekolah Tinggi Teknik PLN \\ 1darmana@gmail.com
}

\begin{abstract}
ABSTRAK
Energi merupakan kebutuhan dasar manusia, yang terus meningkat sejalan dengan tingkat kehidupannya. Bahan bakar minyak/energi fosil merupakan salah satu sumber energi yang bersifat tak terbarukan (nonrenewable energy sources) yang selama ini merupakan andalan untuk memenuhi kebutuhan energi di seluruh sektor kegiatan. Kurangnya pemahaman masyarakat mengenai proses terjadinya energi listrik membuat mereka belum banyak melakukan penghematan energi listrik dalam kehidupan sehari-hari. Selama ini, sebagaian besar siswa dalam menggunakan energi listrik tidak memikirkan dampaknya terhadap kelestarian lingkungan hidup. Kegiatan sosialisasi energi baru dan terbarukan adalah merupakan upaya atau langkah yang dilakukan untuk mengurangi ketergantungan terhadap energi fosil dan sekaligus menjaga kelestarian lingkungan. Kegiatan ini merupakan kegiatan sosialisasi yang dimotori oleh para dosen STT-PLN untuk memberikan edukasi kepada masyarakat tentang pentingnya memahami penggunaan energi listrik secara bijak dalam upaya menjaga lingkungan.
\end{abstract}

Kata kunci: Sosialisasi, Energi Baru Terbarukan, Lingkungan

\begin{abstract}
Energy is a basic human need, which continues to increase in line with the level of life. Oil fuel/fossil energy is one of the nonrenewable energy sources which has been a mainstay to meet energy needs in all sectors of activity. The lack of peoples understanding of the process of the occurrence of electrical energy makes them not much to save electricity in everyday life. During this time, most students in using electrical energy do not think about the impact on environmental sustainability. The activity of disseminating new and renewable energy is an effort or step taken to reduce dependence on fossil energy and simultaneously preserve the environment. This activity is a socialization activity led by STT-PLN lecturers to provide education to the public about the importance of understanding the use of electrical energy wisely in an effort to protect the environment.
\end{abstract}

Keywords: Socialization, Renewable Energy, Environment 


\section{PENDAHULUAN}

Sumber energi baru terbarukan adalah sumber energi ramah lingkungan yang tidak mencemari lingkungan dan tidak memberikan kontribusi terhadap perubahan iklim dan pemanasan global, karena energi yang didapatkan berasal dari proses alam yang berkelanjutan, seperti sinar matahari, angin, air, biofuel, dan geothermal. Ini menegaskan bahwa sumber energi telah tersedia, tidak merugikan lingkungan, dan menjadi alasan utama mengapa EBT sangat terkait dengan masalah lingkungan dan ekologi. Persoalan energi merupakan kepentingan semua negara di dunia. Energi bukanlah merupakan komoditas biasa, akan tetapi merupakan komoditas strategis mengingat seluruh sistem dan dinamika kehidupan manusia dan negara tergantung kepada energi sebagai urat nadi kehidupan pada semua sektor. Program pemerintah dalam rangka mewujudkan kemandirian energi nasional bukanlah hal yang mustahil untuk dicapai. Keseriusan pemerintah yakni bagaimana terus meningkatkan pasokan energi dengan memaksimalkan berbagai potensi yang dimiliki dan belum tergarap maksimal. Pengembangan pemanfaatan EBT merupakan upaya yang harus didukung penuh oleh seluruh lapisan masyarakat. Ketergantungan akan energi fosil yang semakin menipis cadangannya akan membuat Indonesia terjerembab dalam krisis energi. Sejatinya, antisipasi terhadap krisis energi bisa diatasi yaitu dengan terus melakukan pemanfaatan terhadap EBT (ESDM, 2016).

Saat ini energi yang dinikmati oleh masyarakat di Indonesia, khususnya listrik berbahan baku batu bara, minyak bumi, dan gas bumi. Bahan baku tersebut merupakan sumber energi fosil yang tidak terbarukan. Energi listrik yang kita nikmati berupa cahaya lampu, mobil atau motor yang dipakai untuk bepergian, sumbernya kebanyakan dari batu bara, minyak bumi, dan gas bumi. Itu semua barang yang tidak terbarukan dan suatu saat habis.

Sumber energi tersebut tidak bisa diperbaharui dan pada masa mendatang akan habis. Padahal, 95\% listrik yang dinikmati di Tanah Air berasal dari sumber energi tersebut. Kalau selama ini, 95\% dari energi yang kita nikmati itu datangnya dari energi fosil yang ketersediaannya lama kelamaan akan habis. Di luar itu, juga isu lingkungan mengemuka. Karena energi fosil pada gilirannya menurut hasil penelitian memberikan kontribusi terhadap pencemaran udara.

Eksploitasi sumber daya alam tentunya memberikan dampak negatif dari segi kualitas sumber daya alam itu sendiri. Ditemukannya fakta penurunan kualitas air danau, kualitas udara diperkotaan, pencemaran tanah akibat penggunaan bahan kimia di lahan pertanian dan sebagainya. Besarnya dampak tersebut sangat bergantung pada pola dan perilaku konsumsi, produksi dan distribusi sumber daya alam yang dilakukan (Asmin, 2017).

Perubahan iklim saat ini menjadi perhatian utama masyarakat dunia dikarenakan oleh efeknya yang menyebabkan naiknya temperatur rata-rata dunia secara tidak wajar. Peristiwa ini mengakibatkan terganggunya keseimbangan lingkungan, juga membahayakan kesehatan dan cadangan kebutuhan pangan manusia. Penyebab utama dari perubahan iklim adalah aktivitas produksi listrik yang didominasi oleh pembangkit listrik tenaga batubara dan pembangkit listrik tenaga gas bumi yang mencakup sekitar 30\% dari total emisi gas yang menyebabkan pemanasan global. Di sisi lain, energi terbarukan diduga merupakan sumber energi yang bersih dan tidak memiliki emisi gas rumah kaca. Namun, pada kenyataanya energi terbarukan juga memiliki dampak buruk bagi lingkungan, baik berupa emisi yang dihasilkan ke udara, penggunaan lahan, penggunaan air, dampak pada makhluk hidup dan kesehatan serta masyarakat (Achdiansyah, 2017).

Kegiatan sosialisasi energi baru dan terbarukan adalah merupakan upaya atau langkah yang dilakukan untuk mengurangi ketergantungan terhadap energi fosil dan sekaligus menjaga kelestarian lingkungan. Kegiatan ini merupakan kegiatan sosialisasi yang dimotori oleh para dosen STT-PLN 
untuk memberikan edukasi kepada masyarakat tentang pentingnya memahami penggunaan energi listrik secara bijak dalam upaya menjaga lingkungan.

Dengan memahami latar belakang dan tujuannya, maka diharapkan menjadi agen perubahan, menjadi pelopor, menjadi yang paling depan bagaimana melakukan hemat energi.

\section{METODE}

Metode pelaksanaan yang digunakan dalam pelaksanaan P2M ini adalah :

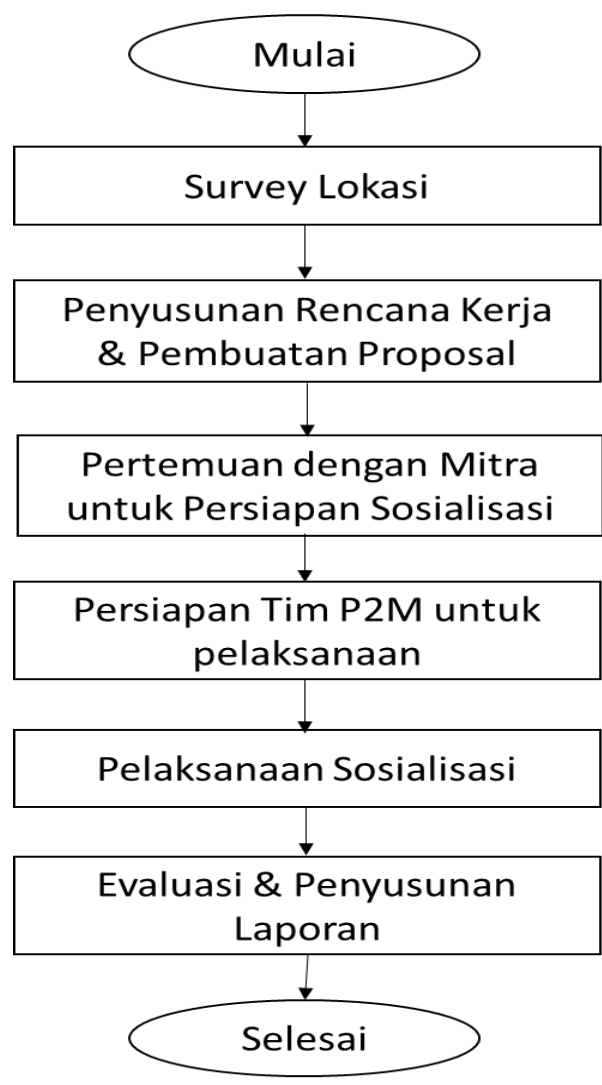

Gambar 1. Diagram Alir P2M

Tahapan dari kegiatan pengabdian kepada masyarakat terdiri atas beberapa tahap yaitu:

(1) Survey ke lokasi mitra untuk menggali lebih lanjut permasalahan dan kebutuhan mitra.

(2) Merencanakan kegiatan pengabdian pada masyarakat dalam upaya sosialisasi tentang pemahaman pembangkit listrik dari energi baru dan terbarukan.

(3) Melaksanakan kegiatan pengabdian pada masyarakat sesuai jadwal yang disepakati antara tim dan mitra.

(4) Melakukan kunjungan ke kampus STT PLN untuk mengenalkan jenis jenis pembangkit listrik yang ramah lingkungan.

(5) Mengevaluasi hasil kegiatan pengabdian pada masyarakat yang dilaksanakan.

(6) Membuat laporan pertanggungjawaban pelaksanaan kegiatan pengabdian pada masyarakat. 
Tabel 1. Metode Pelaksanaan P2M

\begin{tabular}{|c|l|c|}
\hline No. & \multicolumn{1}{|c|}{ Kegiatan } & Waktu \\
\hline 1 & Survey kebutuhan mitra & 6 Februari 2019 \\
\hline 2 & $\begin{array}{l}\text { Melakukan diskusi dengan tim P2M untuk menganalisa kebutuhan dan } \\
\text { permasalahan yang di hadapi mitra }\end{array}$ & 13 Februari 2019 \\
\hline 3 & $\begin{array}{l}\text { Survey kedua membicarakan mengenai format pelaksanaan P2M yang } \\
\text { telah dirancang P2M kepada mitra. }\end{array}$ & 21 Februari 2019 \\
\hline 4 & Mengusulkan proposal P2M kepada LP3M STT-PLN & 13 Maret 2019 \\
\hline 5 & Proposal tim disetujui oleh LPPM STT-PLN & 20 Maret 2019 \\
\hline 6 & $\begin{array}{l}\text { Melakukan rapat koordinasi untuk melakukan persiapan dan } \\
\text { pembagian tugas dalam pelaksanaan P2M }\end{array}$ \\
\hline 7 & Membuat kesepakatan dengan mitra untuk pelaksanaan P2M & 17 April 2019 \\
\hline 8 & Pelaksanaan P2M & 27 April 2019 \\
\hline
\end{tabular}

Sifat kegiatan ini adalah melakukan penyuluhan dan sosialisasi tentang energi baru terbarukan untuk masyarakat Desa Sukawali, Kabupaten Tangerang, Banten dan kaitannya dengan lingkungan hidup.

Setiap masyarakat diberikan penjelasan beberapa jenis pembangkit listrik yang ramah lingkungan dan tidak menimbulkan pencemaran udara, seperti pembangkit listrik tenaga surya (PLTS), pengolahan sampah menjadi briket untuk masak serta bahayanya sampah plastik bagi lingkungan hidup, kemudian dilanjutkan dengan demo perangkat PLTS serta dipertunjukan briket hasil pengolahan sampah.

Adapun langkah-langkah yang dilakukan selama sosialisasi ini adalah sebagai berikut:

Langkah 1 : Peserta diberikan materi tentang jenis jenis pembangkit yang ramah lingkungan, seperti PLTS, PLTB, PLTA.

Langkah 2 : Peserta diberikan contoh komponen komponen PLTS serta cara kerja nya.

Langkah 3 : Peserta diberikan materi tentang pengolahan sampah sederhana yang menghasilkan briket.

Langkah 4 : Peserta diberikan materi tentang dampak penggunaan sampah plastik bagi lingkungan hidup, seperti pencemaran udara dan pencemaran air laut.

Langkah 5 : Setelah penyampaian materi, dilakukan diskusi dan tanya jawab tentang materi yang disampaikan.

Langkah 6 : Peserta diharapkan dapat melanjutkan dan menyebarluaskan informasi tentang energi baru terbarukan kepada kerabat, anggota keluarga dan tetangga sekitarnya.

\section{HASIL DAN PEMBAHASAN}

Kegiatan pengabdian masyarakat yang dilakukan oleh Tim PKM STT PLN di Desa Sukawali Kab. Tangerang, Banten mendapat sambutan dan antusias yang sangat besar. Pemahaman masyarakat tentang pentingnya penggunaan penggunaan air tanah masih belum diimbangi dengan upaya pelestarian lingkungan sekitarnya, serta upaya dalam menghemat energi listrik merupakan bagian dari upaya menjaga lingkungan hidup, masih belum banyak dipahami.

Adapun susunan acara pada kegiatan sosialisasi dapat dilihat pada tabel dibawah ini: 
Tabel 2. Susunan Acara Pelaksanaan P2M

\begin{tabular}{|c|c|c|c|}
\hline No & Waktu & Acara & Penanggung Jawab \\
\hline 1 & 09:00 - 10:00 & Registrasi Peserta & Jumiati \\
\hline 2 & $10: 00-10: 15$ & Pembukaan Acara & Jumiati \\
\hline 3 & $10: 15-10: 45$ & Sambutan Kepala Desa Sukawali & \\
\hline 4 & $10: 45-11.15$ & Sambutan Ketua Tim P2M & Tasdik Darmana \\
\hline 5 & $11: 15-12: 00$ & $\begin{array}{lcccc}\begin{array}{l}\text { Sosialisasi Energi listrik } \\
\text { lingkungan }\end{array} & & & & \\
\end{array}$ & $\begin{array}{l}\text { - Retno Aita } \\
\text { - Syarif Hidayat }\end{array}$ \\
\hline 6 & $12: 00-13: 00$ & ISHOMA & - \\
\hline 7 & $13: 00-15: 00$ & $\begin{array}{l}\text { Sosialisasi Penghematan air tanah dan upaya } \\
\text { menjaga lingkungan hidup }\end{array}$ & $\begin{array}{l}\text { - I Made Indradjaya } \\
\text { - Soetjipto Soewono }\end{array}$ \\
\hline 8 & $15: 00$ & Penutup & $\begin{array}{l}\text { - Jumiati } \\
\text { - Zaenal Arifin }\end{array}$ \\
\hline
\end{tabular}

Kegiatan sosialisasi ini berjalan dengan lancar dan dihadiri sekitar 40 peserta yang terdiri dari orang tua, pemuda dan ibu ibu serta tokoh masyarakat setempat. Besarnya minat masyarakat terhadap kegiatan ini menunjukan betapa pentingnya informasi tentang menjaga kelestarian lingkungan hidup sebagai bentuk untuk menjaga kelangsungan hidup bagi generasi yang akan datang.

Hasil kegiatan P2M secara garis besarnya dapat dilihat berdasarkan beberapa komponen berikut ini :

a. Keberhasilan target jumlah peserta yang mencapai $100 \%$. Hal ini terlihat dari daftar hadir sebanyak 40 orang, dengan mayoritas yang hadir adalah orang tua dan para pemuda. Hal ini didukung hadirnya tokoh masyarakat serta peran Kepala Desa mulai dari persiapan, penyebaran undangan, pengadaan konsumsi, tempat dan peralatan pendukung lainnya.

b. Ketercapaian tujuan sosialisasi mencapai $90 \%$. Hal ini terlihat dari adanya peningkatan pengetahuan peserta dari yang tidak memahami tentang penghematan pemakaian air tanah dalam kaitannya dengan lingkungan hidup sampai memahami bagaimana upaya dalam menjaga lingkungan hidup.

c. Meningkatnya pemahaman masyarakat tentang besaran listrik seperti arus listrik, tegangan dan daya listrik serta hubungannya dengan peralatan listrik seperti jenis kabel listrik, saklar / stop kontak akan berdampak pada pemilihan peralatan listrik.

d. Ketercapaian target materi yang disampaikan mencapai $80 \%$. Hal ini terlihat dari cara mengisi kuesioner yang diberikan oleh Tim PKM mengenai kebutuhan pemakaian listrik dalam kaitannya terhadap beban yang digunakan dirumah tangga serta biaya yang dikeluarkan selama beberapa bulan.

e. Secara keseluruhan kegiatan PKM berupa sosialisasi bahaya dan keselamatan penggunaan listrik di Desa Sukawali Kab. Tangerang, Banten dinilai berhasil, karena manfaatnya langsung dirasakan oleh warga setempat terutama dalam upaya mencegah bahaya kebakaran akibat listrik. 
Terang : Jurnal Pengabdian Pada Masyarakat Menerangi Negeri

e-ISSN: $2655-5948$

Vol. 2, No. 1, Desember 2019

p-ISSN: 2655-5956

DOI: https://doi.org/10.33322/terang.v2i1.538

Berikut adalah foto-foto kegiatan pelaksanaan P2M:
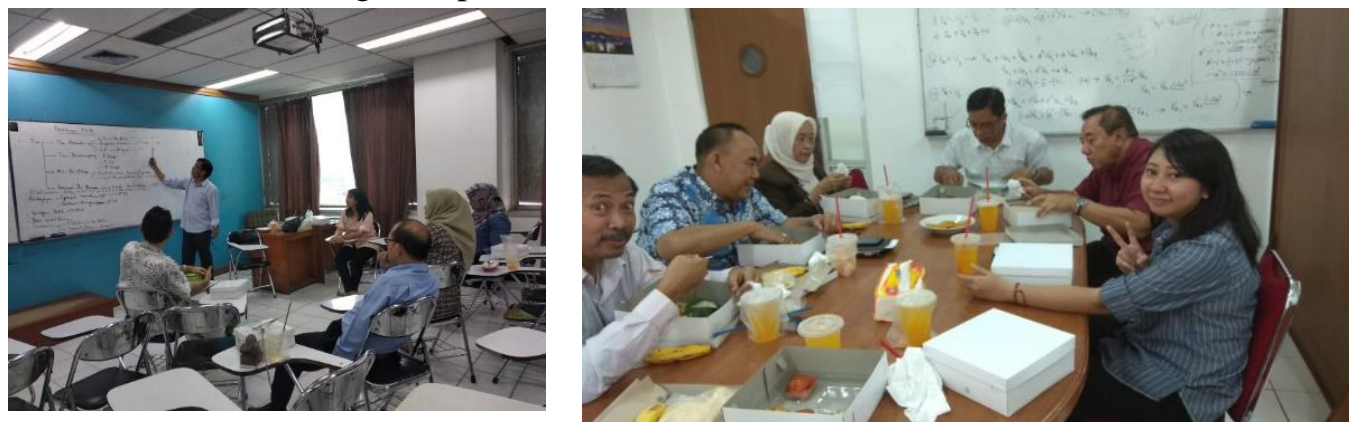

Gambar 2. Rapat persiapan dalam rangka merancang format pelaksanaan P2M
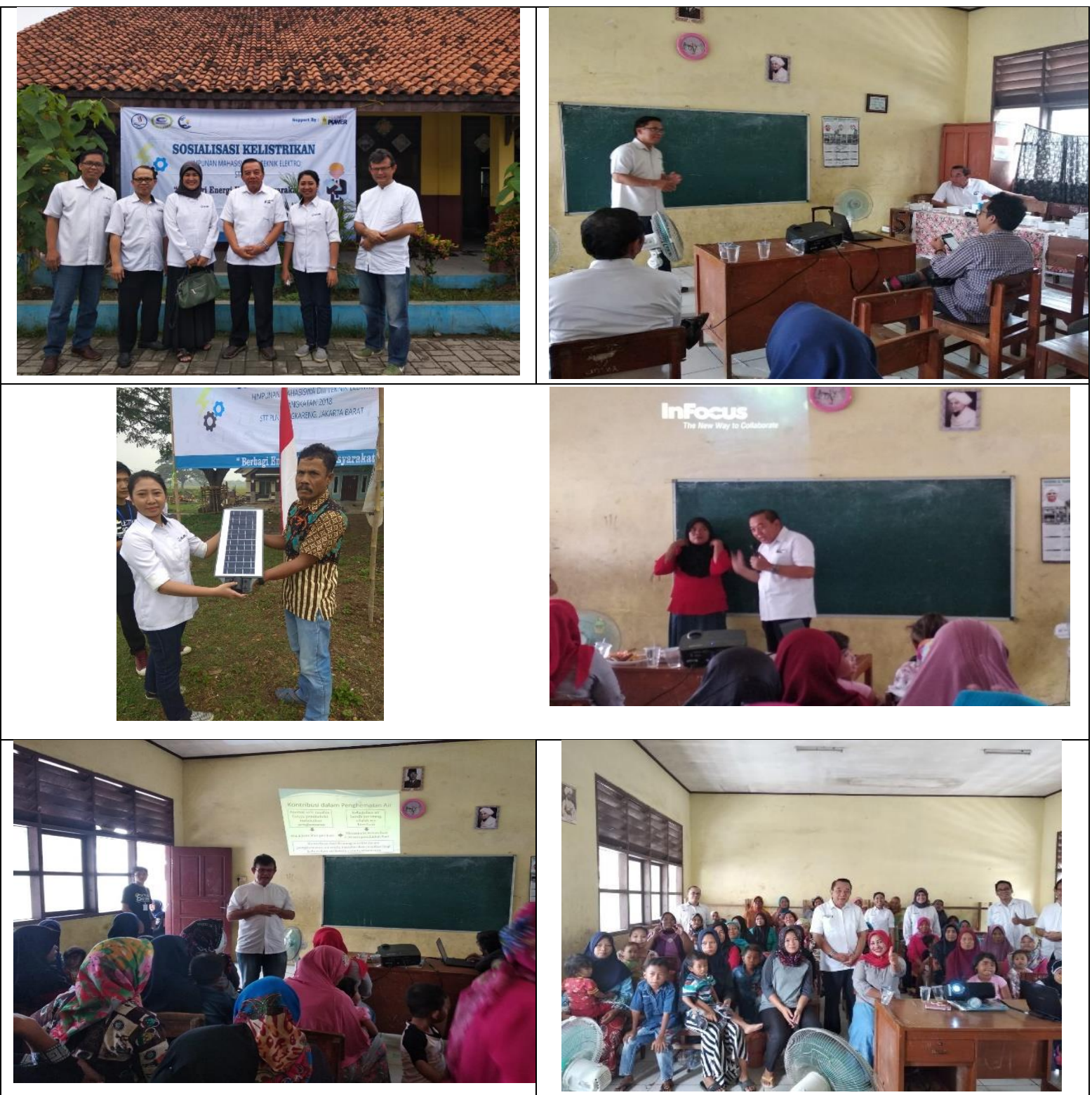

Gambar 3. Pelaksanaan Sosialisasi Energi Baru Terbarukan dan lingkungan Hidup Desa Sukawali Kabupaten Tangerang 


\section{KESIMPULAN}

Dengan dilaksanakannya kegiatan ini, masyarakat di Desa Sukawali Kabupaten Tangerang, Banten dapat meningkatkan pengetahuannya tentang penghematan air secara tepat serta pemahaman mengenai upaya menghemat pemakaian energi listrik dengan baik dan benar.

\section{SARAN}

Sosialisasi yang dilakukan oleh Tim P2M STT PLN dalam upaya penghematan pemakaian air serta menjaga lingkungan sekitarnya dapat memberi dampak positif dan ini merupakan langkah kecil namun memberi nilai yang sangat besar. Untuk itu apa yang sudah dilakukan dalam kegiatan Pengabdian Masyarakat ini dapat dilanjutkan pada semester depan dengan lokasi yang berbeda.

\section{UCAPAN TERIMA KASIH}

Penulis mengucapkan terima kasih khususnya kepada Kepala Desa Sukawali, Kabupaten Tangerang, tokoh agama serta seluruh masyarakat Desa Sukawali yang mengikuti kegiatan ini. Tidak lupa kami ucapkan terima kasih juga kepada Ketua STT-PLN, dan kepada Kepala Departemen Elektro yang telah memberi dukungan yang membantu pelaksanaan kegiatan pengabdian pada masyarakat dan penulisan artikel ini.

\section{DAFTAR PUSTAKA}

[1] Achdiansyah, Y. Y. (2017). Energi Terbarukan dan Dampaknya Terhadap Lingkungan. EBT.

[2] Anonim. (2015). Roadmap Pembangunan Energi Baru Terbarukan Untuk Ketahanan Energi. Dana Mitra Lingkungan.

[3] Asmin, F. (2017). Masalah Lingkungan Hidup di Indonesia.

[4] ESDM. (2016). Mengarusutamakan EBT Sebagai Energi Masa Depan. Jurnal Energi, Media Komunikasi Kementrian Energi dan Sumber Daya Mineral, 9-11.

[5] Kholiq, I. (2015). Pemanfaatan Energi Alternatif Sebagai Energi Terbarukan Untuk Mendukung Substitusi BBM. IPTEK, 75-91. 